\title{
Factors Affecting Future Expectations of 12. Grade Students' Preparation for Higher Education in Schools*
}

\author{
Halime GÜNGÖR**
}

\begin{abstract}
Purpose of research is to determine views of students, teachers and school administrators about factors affecting and extent to which factors affect in what degree to 12th grade students' future expectations in school environment during high school preparation period. Descriptive survey model from quantitative research methods was used in research. Proportional stratified sampling was used to determine study sample. Totally 2509 participants that is 2072 students, 380 teachers and 57 administrators participated in the research. It was concluded that the perceptions of students and teachers differ according to their gender but the perceptions of the administrators do not differ. According to research results, students who attend schools with high success think that school-related factors have more impact on their future expectations than students who have low success. Teachers' and administrators' perceptions do not differ according to the type of school they work in, success of school, and their level of hope for future. Activities aimed at structuring future expectations of students should be planned by school administration and the functionality of guidance services in schools should be increased. School administrators should take the lead in preparing school environment and planning program where teachers can take care of students individually.
\end{abstract}

Keywords: Higher education, school environment, future expectations.

\footnotetext{
${ }^{*}$ This study is produced on the Ph.D. Thesis titled "Factors Affecting 12th Grade Students' Academic Success and Future Expectations at Schools While Preparing for Higher Education", completed by Halime GÜNGÖR under the supervision of Prof. Dr. Şefika Şule ERÇETIN in Hacettepe University, Department of Educational Sciences, Department of Educational Administration, Inspection, Planning and Economics in July 2020. The ethics committee approval for this study was obtained from the Ethics Committee of the Rectorate of Hacettepe University, dated 07/01/2020 and numbered 35853172-300.

** Orcid ID: https://orcid.org/0000-0002-3283-1250, Dr., Ministry of National Education, Turkey, gungor.halime@gmail.com

${ }^{* * *}$ Orcid ID: https://orcid.org/0000-0002-7686-4863, Prof. Dr., Hacettepe University, sefikasule@gmail.com
} 


\section{INTRODUCTION}

The high school period, which is the transition process to adulthood, is a period when young people prepare to make important decisions about their lives such as career choice, transition to higher education, business life, emotional relationships and marriage. These decisions are extremely important as they will affect not only the work life of young people, but also their living standards and life choices. When compulsory education ends at the end of the high school period, young people who have not been able to determine their life goals and who have not made a decision about how they want their life to proceed after high school will be concerned about their future. Since industrialized societies that success is extremely important, anxiety for the future of individuals starts from childhood (Şanlı \& Saraçlı, 2015). Individuals who have not been able to make their plans for their future and who have not realized their expectations will experience despair and stress (Tuncer, 2011a). Future expectations are one of the factors that affect individuals' experiences of their future life. Having a positive experience enables individuals to successfully continue their existing duties and responsibilities, while increasing their expectations for the future, allowing them to make more effort for their future (Tuncer, 2011b).

Although the issue of what future orientations might be and what kind of individual differences might be observed in these orientations has been discussed for a long time, and related researches are very limited on this issue (İmamoğlu \& Güler-Edwards, 2007). It can be said that scientific researches on future expectations started at the beginning of the 21st century (Şimşek, 2012; Şanlı \& Saraçli, 2015; Aktaş, 2016). W. I. Thomas is one of the pioneers of studies on future expectation, argued that the meanings attributed to behaviors or situations by individuals affect future behaviors, and also pointed out that expectations affect the results in 1920 (Şimşek, 2012; Hurn,1993).

Seginer (2003) revealed that the conceptualization of future expectations is based on the early work of Frank (1939), Israeli $(1930,1936)$ and Lewin $(1939,1948)$. In their early studies, researchers emphasized that future behaviors and experiences about future orientation occur in the future, and the contents of individuals' thoughts about the future may be idealistic or realistic thoughts about their own life or social life.

When the literature on future expectations is examined it is seen that three concepts are used as future time perspective (Ehtiyar et al.2017; Calster, Lens, \& Nuttin, 1987), future time attitude (Ehtiyar et al.2017; Nuttin \& Lens, 1985) and future time orientation (İmamoğlu \& Güler-Edwards, 2007; Zimbardo and Boyd, 1999). Future time perspective is about how individuals structure their plans for the future. The future time attitude is related to the level of hope for the future of the individual. In other words, the future time attitude is about how positive or negative feelings about the future shape of their behavior. Future time orientation is the focus of individuals' feelings and thoughts to the moment they live in and direct them to the future. It can be said that some individuals have difficulty in living in now and here due to their experiences; and that individuals who carry the intensity of resentment, anger and negative emotional loads towards 
themselves and other individuals, they mostly lived in the past because they could not close their past accounts and could not focus on now and here, therefore they could not be in the future time orientation. In this context, individuals who have a positive future time orientation are individuals who can focus on the moment and see the future with hope.

Future orientation, defined as individuals' subjective view of their future (Seginer, 2009), shapes how adolescents think about the future, how they perceive the situation and how they act (Negru, Subțirică \& Opre, 2012). The meanings attributed by individuals to behaviors affect their future behavior (Hurn, 1993, Tatar, 2005, Şimşek 2012). Future expectation can be defined as the experiences that individuals hope to realize in their future lives. While positive future expectations increase individuals' hopes for the realization of their expectations, negative future expectations decrease individuals' hopes and motivations. It can be said that adolescents' expectations from the future generally include thoughts such as completing their education, gaining success in business life, and getting married (Şimşek, 2012).

Individuals are expected to set realistic, measurable and achievable goals in the process of realizing their expectations, to plan in order to reach the set goal, to implement this plan with responsibility and motivation to achieve goals, to develop solutions by evaluating the problems in the process and to reach the goal. In this sense, the realization of the future expectations of individuals also contributes to the development of societies. The high expectations and hopes of young people from the future affect both their mental-emotional health and their level of life satisfaction, while contributing society (Yavuzer et al. 2005). Therefore, educators, researchers and other key stakeholders in the education system must deal with questions in the field of education that they are reluctant to hear (Erçetin \& Bisaso, 2018). Educational administrators are the people who will manage and guide the practices that should be done in schools to increase the future expectations of students. In this sense, administrators should know to what extent which factors affect future expectations and precautions should be taken accordingly. Purpose of research is to determine views of students, teachers and school administrators about factors affecting and extent to which factors affect in what degree to $12^{\text {th }}$ grade students' future expectations in school environment during the high school preparation period. As a result of the research, it will be determined to what extent factors related to the future expectations of the school will be determined, so it will help school administrators to determine the areas that they should give priority in the education and training process in their schools, and to see their strengths and weaknesses that need to be improved.

\section{METHOD}

Descriptive survey model from quantitative research methods was used in the research. Proportional stratified sampling type of stratified sampling method was used to determine the study sample. The ethics committee approval for this study was obtained 
from the Ethics Committee of the Rectorate of Hacettepe University, dated 07/01/2020 and numbered 35853172-300. The study sample was planned to be composed of 12th grade students, teachers and school administrators of 24 schools determined as stratum in 17 districts of Bursa province. Since the number of schools in Büyükorhan, Harmancik, Keles and Orhaneli districts is low, there were no schools included in the sampling as a result of sample calculations. In the districts of Gemlik, Gürsu, İznik, Karacabey, Kestel, Mudanya, Mustafakemalpaşa, Orhangazi and Yenişehir, the sample was calculated as 1 school. In these districts, 2 schools instead of 1 were included to the sample. Sample Characteristics are given in Table 1.

Table 1

Sample Characteristics

\begin{tabular}{llll}
\hline Districts & $\begin{array}{l}\text { 12th Grade } \\
\text { Students }\end{array}$ & Teachers & Administrators \\
\hline Gemlik & 183 & 7 & 3 \\
Gürsu & 98 & 19 & 4 \\
İnegöl & 229 & 59 & 7 \\
İznik & 59 & 16 & 2 \\
Karacabey & 50 & 9 & 5 \\
Kestel & 147 & 20 & 5 \\
Mudanya & 170 & 32 & 4 \\
Mustafakemalpaşa & 56 & 15 & 3 \\
Nilüfer & 172 & 25 & 3 \\
Orhangazi & 94 & 21 & 2 \\
Osmangazi & 574 & 81 & 12 \\
Yenişehir & 51 & 17 & 3 \\
Ylldrrım & 189 & 59 & 4 \\
Total & 2072 & 380 & 57 \\
\hline General Total & 2509 & & \\
\hline
\end{tabular}

Totally 2509 participants that is 2072 students, 380 teachers and 57 administrators participated in the research. The personal information form prepared by the researchers and the Future Expectations Scale developed by Erçetin, Güngör, Hamedoğlu (2020) were used as data collection tools. According to the Exploratory Factor Analysis and Partial Least Squares Structural Equation Modeling (PLS-SEM); the scale consists of 5 dimensions and 25 items: school administrators and management style, parents' 
contribution, teacher-based factors, school qualifications, and the effect of students' individual characteristics. In the validity and reliability study of the scale, the Cronbach alpha coefficient for the first dimension was calculated as .905 , for the second dimension as .872 , for the third dimension as .884 , for the fourth dimension as .882 , for the fifth dimension as .854 . In this study, the reliability coefficient of the scale was measured as .89 for the first, second, third and fourth dimensions, .88 for the fifth dimension, and .93 for the whole. The data collection tools were applied by the researcher personally by going to the schools in February and March of the 2019-2020 academic year.

First of all, whether the scores of variables falling into the specified categories of variables for each dimension were suitable for normal distribution was tested with Kolmogorov Simirnov Test, and whether the homogeneity condition of variances were tested with Levene's Test. Normality test result of the research sample is given in Table 2.

Table 2

Normality Test Results

\begin{tabular}{|c|c|c|c|c|c|c|c|c|}
\hline \multicolumn{3}{|c|}{ Participants } & FEF1 & FEF2 & FEF3 & FEF4 & FEF5 & FETotal \\
\hline \multirow{8}{*}{ 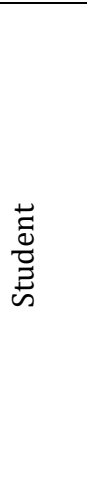 } & \multicolumn{2}{|l|}{$\mathrm{N}$} & 2072 & 2072 & 2072 & 2072 & 2072 & 2072 \\
\hline & Normal & Mean & 19,5323 & 20,3808 & 19,7486 & 19,7346 & 20,6105 & 100,0068 \\
\hline & Parameters ${ }^{\mathrm{a}, \mathrm{b}}$ & Std. D. & 5,05421 & 4,73073 & 4,76568 & 4,97235 & 4,66433 & 21,31575 \\
\hline & Most Extreme & Absolute & 140 & ,164 & 135 & ,145 & ,173 & 120 \\
\hline & Differences & Positive & 140 & ,164 & 135 & 145 & ,173 & ,120 \\
\hline & & Negative &,- 113 &,- 143 &,- 115 &,- 130 &,- 150 &,- 094 \\
\hline & \multicolumn{3}{|c|}{ Kolmogorov-Smirnov Z } & 140 & 164 & ,135 & 145 & 173 \\
\hline & \multicolumn{3}{|c|}{ Asymp. Sig. (2-tailed) } & ,000 & ,000 & ,000 & ,000 &, 000 \\
\hline \multirow{8}{*}{ 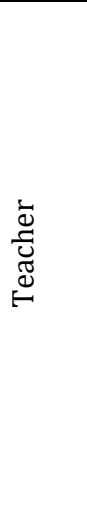 } & \multicolumn{2}{|l|}{$\mathrm{N}$} & 380 & 380 & 380 & 380 & 380 & 380 \\
\hline & Normal & Mean & 21,3184 & 21,8211 & 21,3816 & 21,5263 & 21,9263 & 107,9737 \\
\hline & Parameters ${ }^{\mathrm{a}, \mathrm{b}}$ & Std. D. & 3,69927 & 3,72605 & 3,51614 & 3,76021 & 3,47700 & 16,42057 \\
\hline & Most Extreme & Absolute & 160 & 197 & ,152 & ,178 & 188 & ,150 \\
\hline & Differences & Positive & ,160 & 197 & ,152 & ,178 & 188 & ,150 \\
\hline & & Negative &,- 128 &,- 181 &,- 145 &,- 160 &,- 164 &,- 113 \\
\hline & \multicolumn{3}{|c|}{ Kolmogorov-Smirnov Z } & ,160 & 197 & ,152 & 178 & 188 \\
\hline & \multicolumn{3}{|c|}{ Asymp. Sig. (2-tailed) } &, 000 &, 000 & ,000 & ,000 &, 000 \\
\hline \multirow{3}{*}{ 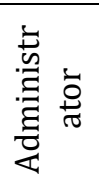 } & \multicolumn{2}{|l|}{$\mathrm{N}$} & 57 & 57 & 57 & 57 & 57 & 57 \\
\hline & Normal & Mean & 20,9298 & 21,3509 & 20,7544 & 20,9123 & 21,4035 & 105,3509 \\
\hline & Parameters ${ }^{a, b}$ & Std. D. & 3,91818 & 3,93923 & 4,26899 & 3,95186 & 3,83061 & 18,69252 \\
\hline
\end{tabular}




\begin{tabular}{llllllll}
\hline Most Extreme & Absolute &, 149 &, 177 &, 160 &, 150 &, 174 &, 147 \\
Differences & Positive &, 149 &, 177 &, 160 &, 150 &, 174 &, 147 \\
& Negative &,- 134 &,- 174 &,- 149 &,- 146 &,- 142 &,- 104 \\
\multicolumn{2}{l}{ Kolmogorov-Smirnov Z } & &, 149 &, 177 &, 160 &, 150 &, 174 \\
Asymp. Sig. (2-tailed) & & ,003 & ,000 & ,001 & ,003 & ,000
\end{tabular}

According to Table 2, we can say that the distribution of the research sample is not normal. In nonparametric tests Mann-Whitney $U$ test and in parametric tests t-test were used to test the difference between two categories of the variable, Kruskal-Wallis for testing the difference when more than two categories in nonparametric tests, ANOVA for parametric tests was used. Mann-Whitney U was used according to the Kruskal-Wallis test result, for multiple comparisons of results found to be statistically significant; Scheffe Test was used according to the ANOVA test result, for multiple comparisons of results found to be statistically significant (Büyüköztürk, 2010; Can, 2017).

\section{FINDINGS}

Descriptive statistics of the perceptions of students, teachers and administrators regarding the school-related factors that affect the future expectations of the students are presented in Table 3.

Table 3

Descriptive Statistics of Perceptions of Students, Teachers and Administrators Regarding School-Related Factors That Affect Students' Future Expectations

\begin{tabular}{|c|c|c|c|c|c|c|c|}
\hline Variables & Group & $\mathrm{N}$ & $\overline{\mathrm{X}}$ & sd & Max. & Min. & Level \\
\hline \multirow{3}{*}{$\begin{array}{l}\text { Future } \\
\text { Expectations }\end{array}$} & Student & 2072 & 4.00 & .85 & 1 & 5 & high level \\
\hline & Teacher & 380 & 4.32 & .66 & 1 & 5 & $\begin{array}{l}\text { the highest } \\
\text { level }\end{array}$ \\
\hline & Administrator & 57 & 4.21 & .75 & 1 & 5 & $\begin{array}{l}\text { the highest } \\
\text { level }\end{array}$ \\
\hline $\begin{array}{l}\text { 1. School } \\
\text { administrators }\end{array}$ & Student & 2072 & 3.91 & 1.01 & 1 & 5 & high level \\
\hline $\begin{array}{l}\text { and } \\
\text { management }\end{array}$ & Teacher & 380 & 4.26 & .74 & 1 & 5 & $\begin{array}{l}\text { the highest } \\
\text { level }\end{array}$ \\
\hline
\end{tabular}




\begin{tabular}{|c|c|c|c|c|c|c|c|}
\hline style & Administrator & 57 & 4.19 & .78 & 1 & 5 & high level \\
\hline \multirow{3}{*}{$\begin{array}{l}\text { 2. Parents' } \\
\text { contribution }\end{array}$} & Student & 2072 & 4.08 & .95 & 1 & 5 & high level \\
\hline & Teacher & 380 & 4.36 & .74 & 1 & 5 & $\begin{array}{l}\text { the highest } \\
\text { level }\end{array}$ \\
\hline & Administrator & 57 & 4.27 & .79 & 1 & 5 & $\begin{array}{l}\text { the highest } \\
\text { level }\end{array}$ \\
\hline \multirow{3}{*}{$\begin{array}{l}\text { 3. Teacher- } \\
\text { based factors }\end{array}$} & Student & 2072 & 3.95 & .95 & 1 & 5 & high level \\
\hline & Teacher & 380 & 4.28 & .70 & 1 & 5 & $\begin{array}{l}\text { the highest } \\
\text { level }\end{array}$ \\
\hline & Administrator & 57 & 4.15 & .85 & 1 & 5 & high level \\
\hline \multirow{3}{*}{$\begin{array}{l}\text { 4. School } \\
\text { qualifications }\end{array}$} & Student & 2072 & 3.95 & .99 & 1 & 5 & high level \\
\hline & Teacher & 380 & 4.30 & .75 & 1 & 5 & $\begin{array}{l}\text { the highest } \\
\text { level }\end{array}$ \\
\hline & Administrator & 57 & 4.18 & .79 & 1 & 5 & high level \\
\hline \multirow{3}{*}{$\begin{array}{l}\text { 5. Effect of } \\
\text { students' } \\
\text { individual } \\
\text { characteristics }\end{array}$} & Student & 2072 & 4.12 & .93 & 1 & 5 & high level \\
\hline & Teacher & 380 & 4.38 & .69 & 1 & 5 & $\begin{array}{l}\text { the highest } \\
\text { level }\end{array}$ \\
\hline & Administrator & 57 & 4.28 & .77 & 1 & 5 & $\begin{array}{l}\text { the highest } \\
\text { level }\end{array}$ \\
\hline
\end{tabular}

When Table 3 is examined, it is seen that the average value of teachers' perceptions about the school-related factors that affect students' future expectations are realized as $\overline{\mathrm{X}}=4.32$, the perceptions of administrators as $\overline{\mathrm{x}}=4.21$, and perceptions of students as $\overline{\mathrm{X}}=$ 4.00. It can be said that teachers and administrators think that school-related factors affect students' future expectations at the highest level, while students think that it affects at high level. When the averages of the sub-dimensions of the scale are examined, it is seen that the highest average according to the perceptions of students, teachers and administrators is realized in the dimension of the effect of students' individual characteristics (student $\overline{\mathrm{x}}=4.12$, teacher $\overline{\mathrm{x}}=4.38$, administrator $\overline{\mathrm{x}}=4.28$ ). When the averages of perceptions of teachers and students in the sub-dimensions of the scale are examined, it is seen that the lowest average is realized in the dimension of school administrators and management style (teacher $\bar{x}=4.26$, student $\bar{x}=3.91$ ), and according to the perceptions of the administrators the lowest average is realized in the dimension of school qualifications ( $\overline{\mathrm{x}}=4.18)$. As a matter of fact, all groups agree that the most influencing factor for future expectations is the individual characteristics of the students. While teachers and students think that the least affecting factor is the school 
administration and management style, administrators think differently on this issue. The results of the Kruskal-Wallis Test for comparing the perceptions of the students, teachers and administrators regarding the school-related factors that affect the future expectations of the students are presented in Table 4.

Table 4

Kruskal Wallis Test Results on Perceptions of Students, Teachers and Administrators Regarding School-Related Factors Affecting Students' Future Expectations

\begin{tabular}{|c|c|c|c|c|c|c|c|}
\hline Variables & Group & $\mathrm{N}$ & $\bar{X}$ & $\begin{array}{l}\text { Rank } \\
\text { Avarage }\end{array}$ & $\chi^{2}$ & $\mathrm{p}$ & Difference \\
\hline \multirow{4}{*}{$\begin{array}{l}\text { Future } \\
\text { Expectations }\end{array}$} & Student & 2072 & 4.00 & 1210.53 & \multirow{4}{*}{45.673} & \multirow{4}{*}{$.000^{*}$} & \multirow{4}{*}{$\begin{array}{l}\text { Student- } \\
\text { Teacher }\end{array}$} \\
\hline & Teacher & 380 & 4.32 & 1477.72 & & & \\
\hline & Administrator & 57 & 4.21 & 1386.61 & & & \\
\hline & Total & 2509 & 4.05 & & & & \\
\hline \multirow{4}{*}{$\begin{array}{l}\text { 1. School } \\
\text { administrators } \\
\text { and } \\
\text { management } \\
\text { style }\end{array}$} & Student & 2072 & 3.91 & 1215.01 & \multirow{4}{*}{37.241} & \multirow{4}{*}{$.000^{*}$} & \multirow{4}{*}{$\begin{array}{l}\text { Student- } \\
\text { Teacher }\end{array}$} \\
\hline & Teacher & 380 & 4.26 & 1453.57 & & & \\
\hline & Administrator & 57 & 4.19 & 1384.76 & & & \\
\hline & Total & 2509 & 3.96 & & & & \\
\hline \multirow{4}{*}{$\begin{array}{l}\text { 2. Parents' } \\
\text { contribution }\end{array}$} & Student & 2072 & 4.08 & 1219.99 & \multirow{4}{*}{29.012} & \multirow{4}{*}{$.000^{*}$} & \multirow{4}{*}{$\begin{array}{l}\text { Student- } \\
\text { Teacher }\end{array}$} \\
\hline & Teacher & 380 & 4.36 & 1430.68 & & & \\
\hline & Administrator & 57 & 4.27 & 1356.51 & & & \\
\hline & Total & 2509 & 4.12 & & & & \\
\hline \multirow{4}{*}{$\begin{array}{l}\text { 3. Teacher- } \\
\text { based factors }\end{array}$} & Student & 2072 & 3.95 & 1217.58 & \multirow{4}{*}{32.807} & \multirow{4}{*}{$.000 *$} & \multirow{4}{*}{$\begin{array}{l}\text { Student- } \\
\text { Teacher }\end{array}$} \\
\hline & Teacher & 380 & 4.28 & 1442.08 & & & \\
\hline & Administrator & 57 & 4.15 & 1367.93 & & & \\
\hline & Total & 2509 & 4.00 & & & & \\
\hline \multirow{3}{*}{$\begin{array}{l}\text { 4. School } \\
\text { qualifications }\end{array}$} & Student & 2072 & 3.95 & 1213.99 & \multirow{3}{*}{39.795} & \multirow{3}{*}{$.000 *$} & \multirow{3}{*}{$\begin{array}{l}\text { Student- } \\
\text { Teacher }\end{array}$} \\
\hline & Teacher & 380 & 4.30 & 1462.83 & & & \\
\hline & Administrator & 57 & 4.18 & 1360.16 & & & \\
\hline
\end{tabular}




\begin{tabular}{llllllll} 
& Total & 2509 & 4.01 & & & \\
\hline $\begin{array}{l}\text { 5. Effect of } \\
\text { students' }\end{array}$ & Student & 2072 & 4.12 & 1226.02 & & & \\
$\begin{array}{l}\text { individual } \\
\text { characteristics }\end{array}$ & Teacher & 380 & 4.38 & 1404.98 & & & \\
& Administrator & 57 & 4.28 & 1308.57 & & & \\
& Total & 2509 & 4.17 & & & & \\
\hline
\end{tabular}

$* \mathrm{p}<.05$

When Table 4 is examined, it is seen that the perceptions of teachers, administrators and students regarding the factors that affect students' future expectations differ statistically significant $\left[\chi^{2}(2)=45.673, \mathrm{p}<.05\right]$. As a result of the multiple comparisons made with the Mann-Whitney U Test, it was found that teachers' perceptions of the factors affecting students' future expectations ( $\overline{\mathrm{x}}=4.32$ high level) were higher than students $(\overline{\mathrm{x}}=4.00$ low level) and this difference was statistically significant. When the scores related to the sub-dimensions of the scale are examined, it is seen that there is a statistically significant difference in all dimensions according to the views of teachers, students and administrators, in all sub-dimensions teachers (respectively $\overline{\mathrm{x}}=4.26$ the highest level, $\overline{\mathrm{x}}$ $=4.36$ the highest level, $\overline{\mathrm{x}}=4.28$ the highest level, $\overline{\mathrm{x}}=4.30$ the highest level, $\overline{\mathrm{x}}=4.38$ the highest level) students (respectively $\bar{x}=3.91$ high level, $\bar{x}=3.96$ high level, $x$ üst $=3.95$ high level, $\bar{x}=3.95$ high level, $x,=4.12$ high level) seems to be. The results of the MannWhitney U Test according to the gender of their own perceptions of the school-related factors that affect students' future expectations are presented in Table 5.

Table 5

Mann-Whitney U Test According to the Gender of Their Own Perceptions of the SchoolRelated Factors that Affect Students' Future Expectations

\begin{tabular}{|c|c|c|c|c|c|c|}
\hline Variables & Sex & $\mathrm{N}$ & $\overline{\mathrm{X}}$ & Rank Av. & $\mathrm{U}$ & $\mathrm{p}$ \\
\hline \multirow{3}{*}{ Future Expectations } & Female & 1152 & 4.12 & 1128.17 & \multirow{3}{*}{424318.000} & \multirow{3}{*}{$.000^{*}$} \\
\hline & Male & 920 & 3.86 & 921.72 & & \\
\hline & Total & 2072 & 4.00 & & & \\
\hline \multirow{3}{*}{$\begin{array}{l}\text { 1. School } \\
\text { administrators and } \\
\text { management style }\end{array}$} & Female & 1152 & 3.99 & 1097.25 & \multirow{3}{*}{459931.000} & \multirow{3}{*}{$.000^{*}$} \\
\hline & Male & 920 & 3.80 & 960.43 & & \\
\hline & Total & 2072 & 3.91 & & & \\
\hline \multirow{2}{*}{$\begin{array}{l}\text { 2. Parents' } \\
\text { contribution }\end{array}$} & Female & 1152 & 4.22 & 1140.90 & \multirow{2}{*}{409653.500} & \multirow{2}{*}{$.000^{*}$} \\
\hline & Male & 920 & 3.90 & 905.78 & & \\
\hline
\end{tabular}




\begin{tabular}{lllllll} 
& Total & 2072 & 4.08 & & & \\
\cline { 6 - 7 } $\begin{array}{l}\text { 3. Teacher-based } \\
\text { factors }\end{array}$ & Female & 1152 & 4.07 & 1119.37 & & \\
& Male & 920 & 3.80 & 932.73 & 434452.500 & $.000^{*}$ \\
& Total & 2072 & 3.95 & & & \\
\hline $\begin{array}{l}\text { 4. School } \\
\text { qualifications }\end{array}$ & Female & 1152 & 4.07 & 1119.03 & & \\
& Male & 920 & 3.79 & 933.16 & 434847.500 & $.000^{*}$ \\
\hline $\begin{array}{l}\text { 5. Effect of students' } \\
\text { individual } \\
\text { characteristics }\end{array}$ & Fotal & 2072 & 3.95 & & & \\
& Male & 920 & 3.98 & 930.01 & 431946.500 & $.000^{*}$ \\
\hline
\end{tabular}

${ }^{*} \mathrm{p}<.05$

When Table 5 is examined, it is seen that students' perceptions of school-related factors that affect their future expectations differ statistically significant according to their gender $(\mathrm{U}=424318.000, \mathrm{p}<.05)$. It was found that female students $(\overline{\mathrm{x}}=4.12$ high level) have higher than male students $(\bar{x}=3.86$ high level). When the sub-dimensions of the scale are examined, it can be said that students' perceptions differ statistically significant in all dimensions according to students' gender. In all sub-dimensions of the scale, it can be said that female students' perceptions (respectively $\bar{x}=3.99$ high level, $\bar{x}=4.22$ the highest level, $\bar{x}=4.07$ high level, $\bar{x}=4.07$ high level, $\bar{x}=4.24$ the highest level) are higher than male students (respectively $\bar{x}=3.80$ high level, $\bar{x}=3.90$ high level, $\bar{x}=3.80$ high level, $\overline{\mathrm{x}}=3.79$ high level, $\overline{\mathrm{x}}=3.98$ high level). The Mann-Whitney U Test results according to the gender of teachers' perceptions about school-related factors that affect students' future expectations are presented in Table 6.

When Table 6 is examined, it is seen that teachers' perceptions of school-related factors that affect students' future expectations differ statistically significant according to their gender $(\mathrm{U}=15658.000, \mathrm{p}<.05)$. It was found that female teachers $(\bar{x}=4.41$ the highest level) had higher perceptions than male teachers ( $\bar{x}=4.24$ the highest level). When the sub-dimensions of the scale are examined, according to teachers' gender teachers' perceptions of factors affecting students' future expectations on parents' contribution (U $=15838.500, \mathrm{p}<.05)$, teacher-based factors $(\mathrm{U}=15505.500, \mathrm{p}<.05)$, school's qualifications $(U=15396.500, p<.05)$, the effect of students' individual characteristics $(\mathrm{U}=15501.500, \mathrm{p}<.05)$ dimensions were found to differ significantly. In the subdimensions of the scale, it can be said that female teachers' perceptions (respectively $\overline{\mathrm{X}}=4.46$ the highest level, $\overline{\mathrm{x}}=4.37$ the highest level, $\overline{\mathrm{x}}=4.42$ the highest level, $\overline{\mathrm{x}}=4.48$ the highest level) are higher than male teachers (respectively $\bar{x}=4.21$ the highest level, $\overline{\mathrm{x}}=4.19$ high level, $\overline{\mathrm{x}}=4.20$ high level, $\overline{\mathrm{x}}=4.30$ the highest level). It can be said that the 
views of male and female teachers are similar in terms of school administrators and management style ( $U=16961.500, p<.05)$. It was found that teachers' perceptions in the dimension of school administrators and management style did not differ significantly according to gender. When the distribution of scores for this dimension is examined, it can be said that the perceptions of female ( $\bar{x}=4.32$ the highest level) teachers are higher than male $(\overline{\mathrm{x}}=4.21$ the highest level) teachers.

Table 6

The Mann-Whitney U Test Results According to the Gender of Teachers' Perceptions about School-Related Factors that Affect Students' Future Expectations

\begin{tabular}{|c|c|c|c|c|c|c|}
\hline Variables & Sex & $\mathrm{N}$ & $\overline{\mathrm{X}}$ & Rank Av. & $\mathrm{U}$ & $\mathrm{p}$ \\
\hline \multirow{3}{*}{ Future Expectations } & Female & 182 & 4.41 & 203.46 & & \\
\hline & Male & 198 & 4.24 & 178.58 & 15658.500 & $.027^{*}$ \\
\hline & Total & 380 & 4.32 & & & \\
\hline \multirow{3}{*}{$\begin{array}{l}\text { 1. School } \\
\text { administrators and } \\
\text { management style }\end{array}$} & Female & 182 & 4.32 & 196.30 & & \\
\hline & Male & 198 & 4.21 & 185.16 & 16961.500 & .317 \\
\hline & Total & 380 & 4.26 & & & \\
\hline \multirow{3}{*}{$\begin{array}{l}\text { 2. Parents' } \\
\text { contribution }\end{array}$} & Female & 182 & 4.46 & 202.48 & & \\
\hline & Male & 198 & 4.28 & 179.49 & 15838.500 & $.037^{*}$ \\
\hline & Total & 380 & 4.36 & & & \\
\hline \multirow{3}{*}{$\begin{array}{l}\text { 3. Teacher-based } \\
\text { factors }\end{array}$} & Female & 182 & 4.37 & 204.30 & & \\
\hline & Male & 198 & 4.19 & 177.81 & 15505.500 & $.017^{*}$ \\
\hline & Total & 380 & 4.28 & & & \\
\hline \multirow{3}{*}{ 4. School qualifications } & Female & 182 & 4.42 & 204.90 & & \\
\hline & Male & 198 & 4.20 & 177.26 & 15396.500 & $.013^{*}$ \\
\hline & Total & 380 & 4.30 & & & \\
\hline \multirow{3}{*}{$\begin{array}{l}\text { 5. Effect of students' } \\
\text { individual } \\
\text { characteristics }\end{array}$} & Female & 182 & 4.48 & 204.33 & & \\
\hline & Male & 198 & 4.30 & 177.79 & 15501.000 & $.016^{*}$ \\
\hline & Total & 380 & 4.38 & & & \\
\hline
\end{tabular}


The Mann-Whitney U Test results according to the gender of administrators' perceptions of school-related factors that affect students' future expectations are presented in Table 7.

Tablo 7

The Mann-Whitney U Test Results According to the Gender of Administrators' Perceptions of School-Related Factors that Affect Students' Future Expectations

\begin{tabular}{|c|c|c|c|c|c|c|}
\hline Variables & Sex & $\mathrm{N}$ & $\overline{\mathrm{X}}$ & $\begin{array}{l}\text { Rank } \\
\text { Av. }\end{array}$ & $\mathrm{U}$ & $\mathrm{p}$ \\
\hline \multirow{3}{*}{ Future Expectations } & Female & 14 & 4.24 & 29.14 & \multirow{3}{*}{299.000} & \multirow{3}{*}{.970} \\
\hline & Male & 43 & 4.21 & 28.95 & & \\
\hline & Total & 57 & 4.21 & & & \\
\hline \multirow{3}{*}{$\begin{array}{l}\text { 1. School } \\
\text { administrators and } \\
\text { management style }\end{array}$} & Female & 14 & 4.20 & 29.93 & \multirow{3}{*}{288.000} & \multirow{3}{*}{.808} \\
\hline & Male & 43 & 4.18 & 28.70 & & \\
\hline & Total & 57 & 4.19 & & & \\
\hline \multirow{3}{*}{$\begin{array}{l}\text { 2. Parents' } \\
\text { contribution }\end{array}$} & Female & 14 & 4.33 & 31.00 & \multirow{3}{*}{273.000} & \multirow{3}{*}{.594} \\
\hline & Male & 43 & 4.25 & 28.35 & & \\
\hline & Total & 57 & 4.27 & & & \\
\hline \multirow{3}{*}{$\begin{array}{l}\text { 3. Teacher-based } \\
\text { factors }\end{array}$} & Female & 14 & 4.11 & 28.11 & \multirow{3}{*}{288.500} & \multirow{3}{*}{.814} \\
\hline & Male & 43 & 4.16 & 29.29 & & \\
\hline & Total & 57 & 4.15 & & & \\
\hline \multirow{3}{*}{$\begin{array}{l}\text { 4. School } \\
\text { qualifications }\end{array}$} & Female & 14 & 4.24 & 29.75 & \multirow{3}{*}{290.500} & \multirow{3}{*}{.843} \\
\hline & Male & 43 & 4.16 & 28.76 & & \\
\hline & Total & 57 & 4.18 & & & \\
\hline \multirow{3}{*}{$\begin{array}{l}\text { 5. Effect of students' } \\
\text { individual } \\
\text { characteristics }\end{array}$} & Female & 14 & 4.33 & 29.75 & \multirow{3}{*}{290.500} & \multirow{3}{*}{.843} \\
\hline & Male & 43 & 4.26 & 28.76 & & \\
\hline & Total & 57 & 4.28 & & & \\
\hline
\end{tabular}

$* \mathrm{p}<.05$

When Table 7 is examined, it is seen that administrators' perceptions of school-related factors that affect students' future expectations do not differ significantly according to 
their gender ( $U=299.000, p>.05)$. In other words, it can be said that the views of male and female administrators regarding the school-related factors that affect students' future expectations are similar. The gender of administrators is not an effective variable on their views on school-related factors that affect students' future expectations. The results of the Kruskal Wallis Test according to the school type of their own perceptions about the school-related factors that affect the future expectations of the students are presented in Table 8.

Table 8

The Results of the Kruskal Wallis Test According to the School Type of Their Own Perceptions about the School-Related Factors that Affect the Future Expectations of the Students

\begin{tabular}{|c|c|c|c|c|c|c|c|}
\hline Variables & $\begin{array}{l}\text { School } \\
\text { Type }\end{array}$ & $\mathrm{N}$ & $\bar{X}$ & Rank Av. & $\chi^{2}$ & $\mathrm{p}$ & Difference \\
\hline \multirow{5}{*}{$\begin{array}{l}\text { Future } \\
\text { Expectations }\end{array}$} & VTAHS & 645 & 3.68 & 812.48 & \multirow{5}{*}{132.794} & \multirow{5}{*}{$.000^{*}$} & \multirow{5}{*}{$\begin{array}{l}\text { VTAHS-SHS } \\
\text { VTAHS -AHS } \\
\text { VTAHS } \\
\text { AİHHS }\end{array}$} \\
\hline & AHS & 993 & 4.14 & 1127.93 & & & \\
\hline & AİHHS & 182 & 4.13 & 1137.77 & & & \\
\hline & SHG & 252 & 4.19 & 1176.46 & & & \\
\hline & Total & 2072 & 4.00 & & & & \\
\hline \multirow{5}{*}{$\begin{array}{l}\text { 1. School } \\
\text { administrators } \\
\text { and } \\
\text { management } \\
\text { style }\end{array}$} & VTAHS & 645 & 3.53 & 817.17 & & & \multirow{5}{*}{$\begin{array}{l}\text { VTAHS -SHS } \\
\text { VTAHS -AHS } \\
\text { VTAHS -AİHL }\end{array}$} \\
\hline & AHS & 993 & 4.07 & 1133.45 & & & \\
\hline & AİHHS & 182 & 4.01 & 1092.99 & 129.606 & $.000^{*}$ & \\
\hline & SHG & 252 & 4.16 & 1175.02 & & & \\
\hline & Total & 2072 & 3.91 & & & & \\
\hline \multirow{5}{*}{$\begin{array}{l}\text { 2. Parents' } \\
\text { contribution }\end{array}$} & VTAHS & 645 & 3.77 & 840.04 & & & \multirow{5}{*}{$\begin{array}{ll}\text { VTAHS } & \text {-SHS } \\
\text { VTAHS } & \text {-AHS } \\
\text { VTAHS } \\
\text { AİHHS }\end{array}$} \\
\hline & AHS & 993 & 4.21 & 1117.84 & & & \\
\hline & AİHHS & 182 & 4.23 & 1139.41 & 103.708 & $.000 *$ & \\
\hline & SHG & 252 & 4.23 & 1144.49 & & & \\
\hline & Total & 2072 & 4.08 & & & & \\
\hline \multirow{3}{*}{$\begin{array}{l}\text { 3. Teacher- } \\
\text { based factors }\end{array}$} & VTAHS & 645 & 3.71 & 891.80 & & & \multirow{3}{*}{$\begin{array}{lr}\text { VTAHS } & \text {-SHS } \\
\text { VTAHS } & \text {-AHS } \\
\text { VTAHS } & -\end{array}$} \\
\hline & AHS & 993 & 4.04 & 1083.27 & 58.960 & $.000^{*}$ & \\
\hline & AİHHS & 182 & 4.10 & 1155.03 & & & \\
\hline
\end{tabular}




\begin{tabular}{|c|c|c|c|c|c|c|c|}
\hline & SHG & 252 & 4.11 & 1136.97 & & & AİHHS \\
\hline & Total & 2072 & 3.95 & & & & \\
\hline \multirow{5}{*}{$\begin{array}{l}\text { 4. School } \\
\text { qualifications }\end{array}$} & VTAHS & 645 & 3.60 & 827.94 & \multirow{5}{*}{117.366} & \multirow{5}{*}{$.000^{*}$} & \multirow{5}{*}{$\begin{array}{ll}\text { VTAHS } & \text {-SHS } \\
\text { VTAHS } & \text {-AHS } \\
\text { VTAHS } \\
\text { AİHHS }\end{array}$} \\
\hline & AHS & 993 & 4.09 & 1121.40 & & & \\
\hline & AİHHS & 182 & 4.07 & 1118.32 & & & \\
\hline & SHG & 252 & 4.18 & 1176.69 & & & \\
\hline & Total & 2072 & 3.95 & & & & \\
\hline \multirow{5}{*}{$\begin{array}{l}\text { 5. Effect of } \\
\text { students' } \\
\text { individual } \\
\text { characteristics }\end{array}$} & VTAHS & 645 & 3.78 & 820.09 & \multirow{5}{*}{126.019} & \multirow{5}{*}{$.000^{*}$} & \multirow{5}{*}{$\begin{array}{l}\text { VTAHS -SHS } \\
\text { VTAHS -AHS } \\
\text { MTAL-AİHHS }\end{array}$} \\
\hline & AHS & 993 & 4.29 & 1138.89 & & & \\
\hline & AİHHS & 182 & 4.23 & 1112.20 & & & \\
\hline & SHG & 252 & 4.27 & \multirow[t]{2}{*}{1132.28} & & & \\
\hline & Total & 2072 & 4.12 & & & & \\
\hline
\end{tabular}

${ }^{*} \mathrm{p}<.05$

When Table 8 is examined, it is seen that students' perceptions of the factors that affect their future expectations differ statistically significant according to the type of school they attend $\left[\chi^{2}(3)=132.794, \mathrm{p}<.05\right]$. As a result of multiple comparisons made with the Mann Whitney U Test, it was found that perception students attending Science High School ( $\overline{\mathrm{x}}=4.19$ high level), students attending Anatolian High School $(\overline{\mathrm{x}}=4.14$ high level) and Anatolian Imam Hatip High School ( $\bar{x}=4.13$ high level) were higher than perceptions of students attending Vocational Technical Anatolian High School $(\bar{x}=3.68$ high level) and these differences were statistically significant. When the scores of the sub-dimensions of the scale are examined, it is seen that in all sub-dimensions, students' perceptions differ statistically significant according to the type of school they attend. In all sub-dimensions, it was found that the perceptions of the students attending Science High School (respectively $\bar{x}=4.16$ high level, $\bar{x}=4.23$ the highest level, $\bar{x}=4.18$ high level, $\overline{\mathrm{x}}=4.18$ high level, $\overline{\mathrm{x}}=4.27$ the highest level), Anatolian High School (respectively $\overline{\mathrm{x}}=4.07$ high level, $\bar{x}=4.21$ the highest level, $\bar{x}=4.04$ high level, $\bar{x}=4.09$ high level, $\bar{x}=4.29$ the highest level) and Anatolian Imam Hatip High School (respectively $\bar{x}=4.01$ high level, $\overline{\mathrm{x}}=4.23$ the highest level, $\overline{\mathrm{x}}=4.10$ high level, $\overline{\mathrm{x}}=4.07$ high level, $\overline{\mathrm{x}}=4.23$ the highest level) about the factors affecting the future expectations were higher than the perceptions of students attending Vocational Technical Anatolian High School (respectively $\bar{x}=3.53$ high level, $\bar{x}=3.77$ high level, $\bar{x}=3.71$ high level, $\bar{x}=3.60$ high level, $\bar{x}=3.78$ high level).

Kruskal Wallis Test results according to the school type of teachers' perceptions about the school-related factors that affect students' future expectations are presented in Table 9. 
Table 9

Kruskal Wallis Test Results According to the School Type of Teachers' Perceptions about the School-Related Factors that Affect Students' Future Expectations

\begin{tabular}{|c|c|c|c|c|c|c|c|}
\hline Variables & $\begin{array}{l}\text { School } \\
\text { Type }\end{array}$ & $\mathrm{N}$ & $\overline{\mathrm{X}}$ & $\begin{array}{l}\text { Rank } \\
\text { Av. }\end{array}$ & $\chi^{2}$ & $\mathrm{p}$ & Difference \\
\hline \multirow{5}{*}{ Future Expectations } & VTAHS & 147 & 4.35 & 187.65 & \multirow{5}{*}{3.083} & \multirow{5}{*}{.379} & \multirow{5}{*}{-} \\
\hline & AHS & 147 & 4.33 & 196.10 & & & \\
\hline & AİHHS & 44 & 4.12 & 167.75 & & & \\
\hline & SHG & 42 & 4.39 & 204.71 & & & \\
\hline & Total & 380 & 4.32 & & & & \\
\hline \multirow{5}{*}{$\begin{array}{l}\text { 1. School } \\
\text { administrators and } \\
\text { management style }\end{array}$} & VTAHS & 147 & 4.28 & 185.22 & \multirow{5}{*}{2.388} & \multirow{5}{*}{.496} & \multirow{5}{*}{-} \\
\hline & AHS & 147 & 4.29 & 198.91 & & & \\
\hline & AİHHS & 44 & 4.09 & 174.05 & & & \\
\hline & SHG & 42 & 4.30 & 196.77 & & & \\
\hline & Total & 380 & 4.26 & & & & \\
\hline \multirow{5}{*}{$\begin{array}{l}\text { 2. Parents' } \\
\text { contribution }\end{array}$} & VTAHS & 147 & 4.37 & 184.79 & \multirow{5}{*}{3.134} & \multirow{5}{*}{.371} & \multirow{5}{*}{-} \\
\hline & AHS & 147 & 4.39 & 199.82 & & & \\
\hline & AİHHS & 44 & 4.20 & 171.28 & & & \\
\hline & SHG & 42 & 4.41 & 197.99 & & & \\
\hline & Total & 380 & 4.36 & & & & \\
\hline \multirow{5}{*}{$\begin{array}{l}\text { 3. Teacher-based } \\
\text { factors }\end{array}$} & VTAHS & 147 & 4.31 & 189.82 & \multirow{5}{*}{4.811} & \multirow{5}{*}{.186} & \multirow{5}{*}{-} \\
\hline & AHS & 147 & 4.29 & 197.08 & & & \\
\hline & AİHHS & 44 & 4.04 & 159.00 & & & \\
\hline & SHG & 42 & 4.36 & 202.85 & & & \\
\hline & Total & 380 & 4.28 & & & & \\
\hline \multirow{5}{*}{$\begin{array}{l}\text { 4. School } \\
\text { qualifications }\end{array}$} & VTAHS & 147 & 4.35 & 193.62 & \multirow{5}{*}{1.300} & \multirow{5}{*}{.729} & \multirow{5}{*}{-} \\
\hline & AHS & 147 & 4.29 & 189.62 & & & \\
\hline & AİHHS & 44 & 4.15 & 174.95 & & & \\
\hline & SHG & 42 & 4.38 & 198.96 & & & \\
\hline & Total & 380 & 4.30 & & & & \\
\hline
\end{tabular}




\begin{tabular}{|c|c|c|c|c|c|c|c|}
\hline \multirow{5}{*}{$\begin{array}{l}\text { 5. Effect of students' } \\
\text { individual } \\
\text { characteristics }\end{array}$} & VTAHS & 147 & 4.42 & 191.02 & \multirow{5}{*}{4.195} & \multirow{5}{*}{.241} & \\
\hline & AHS & 147 & 4.39 & 194.46 & & & \\
\hline & AİHHS & 44 & 4.15 & 161.52 & & & - \\
\hline & SHG & 42 & 4.48 & 205.17 & & & \\
\hline & Total & 380 & 4.38 & & & & \\
\hline
\end{tabular}

$* \mathrm{p}<.05$

When Table 9 is examined, it is seen that teachers' perceptions of school-related factors that affect students' future expectations do not differ statistically significant according to the type of school they work in $\left[\chi^{2}{ }_{(3)}=3.083, \mathrm{p}>.05\right]$, and teachers' views are similar according to the type of school they work.

The results of the Kruskal Wallis Test according to the school type of the administrators' perceptions about the school-related factors that affect the future expectations of the students are presented in Table 10.

Table 10

The Results of the Kruskal Wallis Test According to the School Type of the Administrators' Perceptions about the School-Related Factors that Affect the Future Expectations of the Students

\begin{tabular}{llllllll}
\hline Variables & $\begin{array}{l}\text { School } \\
\text { Type }\end{array}$ & $\mathrm{N}$ & $\overline{\mathrm{X}}$ & $\begin{array}{l}\text { Rank } \\
\text { Av. }\end{array}$ & $\chi^{2}$ & $\mathrm{p}$ & Difference \\
\hline & VTAHS & 26 & 4.11 & 25.94 & & & \\
& AHS & 18 & 4.34 & 31.17 & & & \\
$\begin{array}{l}\text { Future } \\
\text { Expectations }\end{array}$ & AİHHS & 5 & 4.65 & 40.20 & 3.588 & .309 & - \\
& SHG & 8 & 3.98 & 27.06 & & & \\
& Total & 57 & 4.21 & & & & \\
& & & & & & & \\
& VTAHS & 26 & 3.99 & 24.35 & & & \\
$\begin{array}{l}\text { 1. School } \\
\text { administrators and } \\
\text { management style }\end{array}$ & AHS & 18 & 4.42 & 33.47 & & & \\
& SHG & 5 & 4.64 & 39.40 & 5.467 & .141 & - \\
& Total & 5 & 4.00 & 27.56 & & & \\
\hline
\end{tabular}




\begin{tabular}{|c|c|c|c|c|c|c|c|}
\hline \multirow{5}{*}{$\begin{array}{l}\text { 2. Parents' } \\
\text { contribution }\end{array}$} & VTAHS & 26 & 4.19 & 27.17 & \multirow{5}{*}{2.718} & \multirow{5}{*}{.437} & \multirow{5}{*}{-} \\
\hline & AHS & 18 & 4.43 & 31.31 & & & \\
\hline & AİHHS & 5 & 4.64 & 37.50 & & & \\
\hline & SHG & 8 & 3.95 & 24.44 & & & \\
\hline & Total & 57 & 4.27 & & & & \\
\hline \multirow{5}{*}{$\begin{array}{l}\text { 3. Teacher-based } \\
\text { factors }\end{array}$} & VTAHS & 26 & 4.11 & 27.54 & \multirow{5}{*}{2.826} & \multirow{5}{*}{.419} & \multirow{5}{*}{-} \\
\hline & AHS & 18 & 4.17 & 29.33 & & & \\
\hline & AİHHS & 5 & 4.68 & 40.20 & & & \\
\hline & SHG & 8 & 3.90 & 26.00 & & & \\
\hline & Total & 57 & 4.15 & & & & \\
\hline \multirow{5}{*}{$\begin{array}{l}\text { 4. School } \\
\text { qualifications }\end{array}$} & VTAHS & 26 & 4.05 & 26.19 & \multirow{5}{*}{2.916} & \multirow{5}{*}{.405} & \multirow{5}{*}{-} \\
\hline & AHS & 18 & 4.31 & 30.75 & & & \\
\hline & AİHHS & 5 & 4.64 & 39.10 & & & \\
\hline & SHG & 8 & 4.02 & 27.88 & & & \\
\hline & Total & 57 & 4.18 & & & & \\
\hline \multirow{5}{*}{$\begin{array}{l}\text { 5. Effect of } \\
\text { students' individual } \\
\text { characteristics }\end{array}$} & VTAHS & 26 & 4.21 & 27.40 & \multirow{5}{*}{1.627} & \multirow{5}{*}{.653} & \multirow{5}{*}{-} \\
\hline & AHS & 18 & 4.39 & 30.11 & & & \\
\hline & AİHHS & 5 & 4.64 & 36.80 & & & \\
\hline & SHG & 8 & 4.02 & 26.81 & & & \\
\hline & Total & 57 & 4.28 & & & & \\
\hline
\end{tabular}

$* \mathrm{p}<.05$

When Table 10 is analyzed, it is seen that administrators' perceptions of school-related factors that affect students' future expectations do not differ significantly according to the type of school they work in $\left[\chi^{2}(3)=3.588, p>.05\right]$. When the sub-dimensions of the scale are examined, it is seen that administrators' perceptions of school-related factors that affect students' future expectations in all sub-dimensions do not differ statistically significant according to the type of school they work in.

The results of the Mann Whitney U Test according to the success of the school of their own perceptions about the school-related factors that affect the future expectations of the students are presented in Table 11. 
Table 11

The Results of the Mann Whitney U Test According to the Success of the School of Their Own Perceptions about the School-Related Factors that Affect the Future Expectations of the Students

\begin{tabular}{|c|c|c|c|c|c|c|}
\hline Variables & $\begin{array}{l}\text { Success } \\
\text { of School }\end{array}$ & $\mathrm{N}$ & $\overline{\mathrm{X}}$ & Rank Av. & $\mathrm{U}$ & $\mathrm{p}$ \\
\hline \multirow{3}{*}{$\begin{array}{l}\text { Future } \\
\text { Expectations }\end{array}$} & High & 1417 & 4.13 & 1127.64 & \multirow{3}{*}{334925.000} & \multirow{3}{*}{$.000^{*}$} \\
\hline & Low & 655 & 3.72 & 839.34 & & \\
\hline & Total & 2072 & 4.00 & & & \\
\hline \multirow{3}{*}{$\begin{array}{l}\text { 1. School } \\
\text { administrators } \\
\text { and management } \\
\text { style }\end{array}$} & High & 1417 & 4.06 & 1128.27 & \multirow{3}{*}{334025.000} & \multirow{3}{*}{$.000^{*}$} \\
\hline & Low & 655 & 3.58 & 837.96 & & \\
\hline & Total & 2072 & 3.91 & & & \\
\hline \multirow{3}{*}{$\begin{array}{l}\text { 2. Parents' } \\
\text { contribution }\end{array}$} & High & 1417 & 4.21 & 1121.47 & \multirow{3}{*}{343662.500} & \multirow{3}{*}{$.000^{*}$} \\
\hline & Low & 655 & 3.80 & 852.68 & & \\
\hline & Total & 2072 & 4.08 & & & \\
\hline \multirow{3}{*}{$\begin{array}{l}\text { 3. Teacher-based } \\
\text { factors }\end{array}$} & High & 1417 & 4.04 & 1090.93 & \multirow{3}{*}{386938.500} & \multirow{3}{*}{$.000^{*}$} \\
\hline & Low & 655 & 3.76 & 918.75 & & \\
\hline & Total & 2072 & 3.95 & & & \\
\hline \multirow{3}{*}{$\begin{array}{l}\text { 4. School } \\
\text { qualifications }\end{array}$} & High & 1417 & 4.08 & 1119.43 & \multirow{3}{*}{346560.000} & \multirow{3}{*}{$.000^{*}$} \\
\hline & Low & 655 & 3.65 & 857.10 & & \\
\hline & Total & 2072 & 3.95 & & & \\
\hline \multirow{3}{*}{$\begin{array}{l}\text {. Effect of } \\
\text { students' } \\
\text { individual } \\
\text { characteristics }\end{array}$} & High & 1417 & 4.27 & 1128.26 & \multirow{3}{*}{334037.500} & \multirow{3}{*}{$.000^{*}$} \\
\hline & Low & 655 & 3.80 & 837.98 & & \\
\hline & Total & 2072 & 4.12 & & & \\
\hline
\end{tabular}

$* \mathrm{p}<.05$

According to Table 11, it is seen that students' perceptions of school-related factors that affect their future expectations differ statistically significantly according to the success of the school ( $U=334925.000, p<.05)$. It was found that the perceptions of the factors affecting the future expectations of the students who continue to school with high success ( $\overline{\mathrm{x}}=4.13$ high level) are higher than the students who continue to school with low success ( $\overline{\mathrm{x}}=3.72$ high level). When the sub-dimensions of the scale were examined, 
it was found that students' perceptions of factors affecting their future expectations differed statistically significant in all sub-dimensions according to the success of the school students attended. When the scores of the sub-dimensions of the scale are examined, it can be said that the perceptions of the students who attend the school that high success (respectively $\bar{x}=4.06$ high level, $\bar{x}=4.21$ the highest level, $\bar{x}=4.04$ high level, $\overline{\mathrm{x}}=4.08$ high level, $\overline{\mathrm{x}}=4.27$ the highest level) are higher than students who continue to school with low success (respectively $\bar{x}=3.58$ high level, $\bar{x}=3.80$ high level, $\bar{x}=3.76$ high level, $\bar{x}=3.65$ high level, $\bar{x}=3.80$ high level) in all sub-dimensions.

The Mann Whitney U Test results according to the success of the school of teachers' perceptions about school-related factors that affect students' future expectations are presented in Table 12.

Table 12

Mann Whitney U Test Results According to the Success of the School of Teachers' Perceptions about School-Related Factors that Affect Students' Future Expectations

\begin{tabular}{|c|c|c|c|c|c|c|}
\hline Variables & $\begin{array}{l}\text { Success } \\
\text { of School }\end{array}$ & $\mathrm{N}$ & $\overline{\mathrm{X}}$ & Rank Av. & $\mathrm{U}$ & $\mathrm{p}$ \\
\hline \multirow{3}{*}{$\begin{array}{l}\text { Future } \\
\text { Expectations }\end{array}$} & High & 218 & 4.34 & 195.78 & & \\
\hline & Low & 162 & 4.29 & 183.39 & 16506.500 & .276 \\
\hline & Total & 380 & 4.32 & & & \\
\hline \multirow{3}{*}{$\begin{array}{l}\text { 1. School } \\
\text { administrators and } \\
\text { management style }\end{array}$} & High & 218 & 4.28 & 195.08 & & \\
\hline & Low & 162 & 4.24 & 184.33 & 16659.000 & .339 \\
\hline & Total & 380 & 4.26 & & & \\
\hline \multirow{3}{*}{$\begin{array}{l}\text { 2. Parents' } \\
\text { contribution }\end{array}$} & High & 218 & 4.39 & 197.18 & & \\
\hline & Low & 162 & 4.32 & 181.52 & 16202.500 & .160 \\
\hline & Total & 380 & 4.36 & & & \\
\hline \multirow{3}{*}{$\begin{array}{l}\text { 3. Teacher-based } \\
\text { factors }\end{array}$} & High & 218 & 4.30 & 195.35 & & \\
\hline & Low & 162 & 4.25 & 183.97 & 16600.500 & .311 \\
\hline & Total & 380 & 4.28 & & & \\
\hline \multirow{3}{*}{$\begin{array}{l}\text { 4. School } \\
\text { qualifications }\end{array}$} & High & 218 & 4.31 & 191.18 & & \\
\hline & Low & 162 & 4.30 & 189.58 & 17509.000 & .886 \\
\hline & Total & 380 & 4.30 & & & \\
\hline
\end{tabular}




\begin{tabular}{lllllll}
\hline $\begin{array}{l}\text { 5. Effect of } \\
\text { students' individual }\end{array}$ & High & 218 & 4.41 & 194.90 & & \\
characteristics & 162 & 4.35 & 184.58 & 16699.500 & .354 \\
& Total & 380 & 4.38 & & & \\
\hline${ }^{*}<<.05$ & & & & & &
\end{tabular}

When Table 12 is examined, it is seen that teachers' perceptions of school-related factors that affect students' future expectations do not differ statistically significantly according to the success of the school they work in $(U=16506.500, p>.05)$, and teachers' views are similar according to the success of the school they work in. Mann Whitney U Test results according to the success of the school in the perceptions of the administrators about the school-related factors that affect the future expectations of the students are presented in Table 13.

Table 13

Mann Whitney U Test Results According to the Success of the School in the Perceptions of the Administrators about the School-Related Factors that Affect the Future Expectations of the Students

\begin{tabular}{|c|c|c|c|c|c|c|}
\hline Variables & $\begin{array}{l}\text { Success } \\
\text { of School }\end{array}$ & $\mathrm{N}$ & $\bar{X}$ & Rank Av. & $\mathrm{U}$ & $\mathrm{p}$ \\
\hline \multirow{3}{*}{ Future Expectations } & High & 30 & 4.27 & 30.55 & & \\
\hline & Low & 27 & 4.15 & 27.28 & 358.500 & .457 \\
\hline & Total & 57 & 4.21 & & & \\
\hline \multirow{3}{*}{$\begin{array}{l}\text { 1. School administrators } \\
\text { and management style }\end{array}$} & High & 30 & 4.27 & 30.77 & & \\
\hline & Low & 27 & 4.10 & 27.04 & 352.000 & .393 \\
\hline & Total & 57 & 4.19 & & & \\
\hline \multirow{3}{*}{ 2. Parents' contribution } & High & 30 & 4.33 & 30.20 & & \\
\hline & Low & 27 & 4.20 & 27.67 & 369.000 & .555 \\
\hline & Total & 57 & 4.27 & & & \\
\hline \multirow{3}{*}{ 3. Teacher-based factors } & High & 30 & 4.15 & 29.52 & & \\
\hline & Low & 27 & 4.15 & 28.43 & 389.500 & .802 \\
\hline & Total & 57 & 4.15 & & & \\
\hline
\end{tabular}




\begin{tabular}{lllllll}
\hline & High & 30 & 4.29 & 31.48 & & \\
4. School qualifications & Low & 27 & 4.06 & 26.24 & 330.500 & .227 \\
& Total & 57 & 4.18 & & & \\
& High & 30 & 4.33 & 29.97 & & \\
\hline $\begin{array}{l}\text { 5. Effect of students' } \\
\begin{array}{l}\text { individual } \\
\text { characteristics }\end{array}\end{array}$ & Low & 27 & 4.23 & 27.93 & 376.000 & .636 \\
& Total & 57 & 4.28 & & & \\
\hline
\end{tabular}

$* \mathrm{p}<.05$

When Table 13 is examined, it is seen that administrators' perceptions of school-related factors that affect students' future expectations do not differ significantly according to the success of the school they work in ( $U=358.500, p>.05)$. When the sub-dimensions of the scale are examined, it is seen that the perceptions of the administrators regarding the school-related factors that affect the future expectations of the students in all subdimensions do not differ statistically significant according to the success of the school they work. The Mann Whitney U Test results according to the future hope levels of their own perceptions about the school-related factors that affect students' future expectations are presented in Table 14.

Table 14

The Mann Whitney U Test Results According to the Future Hope Levels of Their Own Perceptions about the School-Related Factors that Affect Students' Future Expectations

\begin{tabular}{|c|c|c|c|c|c|c|c|}
\hline Variables & $\begin{array}{l}\text { Hope } \\
\text { Level }\end{array}$ & $\underline{\mathrm{N}}$ & $\underline{\bar{X}}$ & $\begin{array}{l}\text { Rank } \\
\text { Av. }\end{array}$ & $\chi^{2}$ & $\mathrm{p}$ & Difference \\
\hline \multirow{4}{*}{$\begin{array}{l}\text { Future } \\
\text { Expectations }\end{array}$} & High & 836 & 4.07 & 1093.18 & \multirow{4}{*}{17.560} & \multirow{4}{*}{$.000^{*}$} & \multirow{4}{*}{ Medium-High } \\
\hline & Medium & 980 & 3.94 & 978.79 & & & \\
\hline & Low & 256 & 4.02 & \multirow[t]{2}{*}{1072.30} & & & \\
\hline & Total & 2072 & 4.00 & & & & \\
\hline \multirow{4}{*}{$\begin{array}{l}\text { 1. School } \\
\text { administrators } \\
\text { and } \\
\text { management } \\
\text { style }\end{array}$} & High & 836 & 3.99 & 1088.45 & \multirow{4}{*}{18.343} & \multirow{4}{*}{$.000^{*}$} & \multirow{4}{*}{$\begin{array}{l}\text { Medium-High } \\
\text { Medium-Low }\end{array}$} \\
\hline & Medium & 980 & 3.82 & 977.49 & & & \\
\hline & Low & 256 & 3.96 & 1092.74 & & & \\
\hline & Total & 2072 & 3.91 & & & & \\
\hline
\end{tabular}




\begin{tabular}{|c|c|c|c|c|c|c|c|}
\hline \multirow{4}{*}{$\begin{array}{l}\text { 2. Parents' } \\
\text { contribution }\end{array}$} & High & 836 & 4.13 & 1076.45 & \multirow{4}{*}{14.207} & \multirow{4}{*}{$.001^{*}$} & \multirow{4}{*}{$\begin{array}{l}\text { Medium-High } \\
\text { Medium- Low }\end{array}$} \\
\hline & Medium & 980 & 4.02 & 985.41 & & & \\
\hline & Low & 256 & 4.11 & 1101.60 & & & \\
\hline & Total & 2072 & 4.08 & & & & \\
\hline \multirow{4}{*}{$\begin{array}{l}\text { 3. Teacher- } \\
\text { based factors }\end{array}$} & High & 836 & 4.01 & 1083.05 & \multirow{4}{*}{9.410} & \multirow{4}{*}{$.009 *$} & \multirow{4}{*}{ Medium-High } \\
\hline & Medium & 980 & 3.91 & 997.33 & & & \\
\hline & Low & 256 & 3.92 & 1034.41 & & & \\
\hline & Total & 2072 & 3.95 & & & & \\
\hline \multirow{4}{*}{$\begin{array}{l}\text { 4. School } \\
\text { qualifications }\end{array}$} & High & 836 & 4.01 & 1081.70 & \multirow{4}{*}{14.237} & \multirow{4}{*}{$.001^{*}$} & \multirow{4}{*}{$\begin{array}{l}\text { Medium-High } \\
\text { Medium- Low }\end{array}$} \\
\hline & Medium & 980 & 3.88 & 984.58 & & & \\
\hline & Low & 256 & 4.00 & 1087.67 & & & \\
\hline & Total & 2072 & 3.95 & & & & \\
\hline \multirow{4}{*}{$\begin{array}{l}\text { 5. Effect of } \\
\text { students' } \\
\text { individual } \\
\text { characteristics }\end{array}$} & High & 836 & 4.19 & 1094.24 & \multirow{4}{*}{15.728} & \multirow{4}{*}{$.000^{*}$} & \multirow{4}{*}{ Medium-High } \\
\hline & Medium & 980 & 4.06 & 984.31 & & & \\
\hline & Low & 256 & 4.12 & 1047.73 & & & \\
\hline & Total & 2072 & 4.12 & & & & \\
\hline
\end{tabular}

$* \mathrm{p}<.05$

When Table 14 is examined, it is seen that students' perceptions of the factors that affect their future expectations differ statistically significant according to their level of hope for the future $\left[\chi^{2}(2)=17.560, \mathrm{p}<.05\right]$. As a result of the multiple comparisons made with the Mann Whitney U Test, students with high levels of hope for the future $(\bar{x}=4.07$ high level) had higher perceptions than students with medium hope levels $(\overline{\mathrm{x}}=3.94$ high level), and this difference was found to be statistically significant. When the scores of the sub-dimensions of the scale are examined, it is seen that in all sub-dimensions, their own perceptions of the factors affecting future expectations differ statistically significant according to the level of hope for the future. It was found that the perceptions of students with high (respectively $\bar{x}=3.99$ high level, $\bar{x}=4.13$ high level, $\bar{x}=4.01$ high level) and low (respectively $\bar{x}=3.96$ high level, $\bar{x}=4.11$ high level, $\bar{x}=4.00$ high level) levels of hope for the future were higher than students with medium (respectively $\bar{x}=3.82$ high level, $\bar{x}=4.02$ high level, $\bar{x}=3.88$ high level) hope levels in terms of school administrators and management style, parent's contribution and school qualifications dimensions. In the teacher-based factors dimension, it was found that the perceptions of students with high future hope level ( $\bar{x}=4.01$ high level) were higher than students with medium hope 
level ( $\bar{x}=3.91$ high level). In the dimension of the effect of students' individual characteristics, it was found that the perceptions of students with high future hope level $(\bar{x}=4.19$ high level) were higher than students with medium hope level $(\bar{x}=4.06$ high level).

\section{RESULTS, DISCUSSIONS AND SUGGESTIONS}

According to research results teachers and administrators think that school-related factors have a greater effect on students' future expectations than students. In this context, it can be said that school administrators and teachers attribute to school-related factors to get a better future life for students. In addition, teachers, students and administrators thought that the most affected factor for students' future expectations is the individual characteristics of the students. As a result, it was found that gender is effective on perceptions of students and teachers regarding future expectations, but not on the perceptions of administrators. Furthermore, female students think that schoolrelated factors have a greater effect on their future expectations than male students. So, future expectations of male students may be affected more by school-related factors than other factors. In addition, female teachers think that school-related factors have a greater effect on their future expectations than male teachers. Studies in the literature support the results of the research. In the studies conducted by Şimşek (2012) and Aktaş (2016), it was concluded that the future expectations of high school students differ according to their gender.

According to student perceptions, school type is one of the factors affecting future expectations. Students attending Science High School, Anatolian High School and Anatolian Imam Hatip High School think that school-related factors have a greater effect on their future expectations than students who attend Vocational Technical Anatolian High School. It can be said that this situation may differ depending on the development of vocational secondary education and industry cooperation, and it may be due to the fact that it is not easy for students graduated from vocational high schools, who can meet the need for intermediate staff, to find a job. Supporting the results, in the studies conducted by Uluçay, Özpolat, İşgör and Taşkesen (2014) and Şimşek (2012), it was determined that students' future expectations differ according to the type of school. In the study conducted by Aktaş (2016), it was found that the relationship between the psychological resilience and future expectations of adolescents significantly differentiated according to the type of school.

According to research results, students who attend schools with high success think that school-related factors have more impact on their future expectations than students who have low success. It can be said that the academic goals of students who attend high school, finding a job when they complete higher education, and being able to work in a better job with better financial conditions can affect their perceptions of future expectations. 
Furthermore, students with high levels of hope for the future think that school-related factors have a greater effect on their future expectations than students with a high level of hope for the future. It has been observed that students who look more hopeful to the future also have high future expectations. Studies support the relationship between hope level and future expectations. Callina, Johnson, Buckingham, and Lerner (2014) found in their study that there is a direct relationship between hope and future expectations.

All in all, teachers' and administrators' perceptions about the effect of school-related factors on students' future expectations do not differ according to the type of school they work in, the success of the school they work in, and their level of hope for the future. Also, administrators' perceptions about the effect of school-related factors on students' future expectations did not differ according to their gender, different factors may be effective in the opinions of teachers and administrators on this issue. In this context; activities aimed at structuring the future expectations of the students should be planned by the school administration and the functionality of guidance services in schools should be increased. School administrators should take the lead in preparing a school environment and planning program where teachers can take care of students individually. In order to equip the student with application and timely information, a performance evaluation system that will encourage the updating of teachers' knowledge, continuous improvement and renewal should be introduced. School counselors should be motivated by education administrators to carry out activities to structure the future expectations of the students, and the functionality of guidance services should be increased.

\section{References}

Aktaş, E. (2016). Ergenlerin psikolojik dayanıklılıkları ile gelecek beklentileri arasındaki ilişki [The relationship between the psychological resilience of adolescents and their future expectations] (Unpublished Master's Thesis). Ondokuz Mayis University, Institute of Educational Sciences, Department of Guidance \& Psychological Counselling, Samsun.

Büyüköztürk, Ş. (2010). Sosyal bilimler için veri analizi el kitabı: İstatistik, araştırma deseni, SPSS uygulamalarl ve yorum [Data analysis handbook for social sciences: Statistics, research design, SPSS applications and interpretation] (12th Ed). Ankara: PegemA Yayınları

Callina, K. S., Johnson, S. K., Buckingham, M. H., \& Lerner, R. M. (2014). Hope in context: Developmental profiles of trust, hopeful future expectations, and civic engagement across adolescence. Journal of Youth and Adolescence, 43, 6, 869-883. doi:10.1007/s10964-014-0096-9

Calster, K.V. \& Lens, W. \& Nuttin, J.R. (1987). Affevtive attitude toward the personal future time orientations. American Journal of Psychology, 100(1), 1-13 
Can, A. (2017). SPSS ile bilimsel araştırma sürecinde nicel veri analizi [Quantitative data analysis in the scientific research process with SPSS] (5th Ed.). Ankara: Pegem Akademi.

Ehtiyar, R., Ersoy, A., Akgün, A. ve Karapınar, E. (2017). Üniversite öğrencilerinin geleceğe yönelik tutum ve olumlu gelecek beklentilerinin psikolojik iyilik halleri üzerindeki etkisi [The effect of university students' future attitudes and positive future expectations on their psychological well-being]. Mediterranean Journal of Humanities, $7,2,251-262$

Erçetin, Ş. Ş., \& Bisaso S. M. (2018). Contemporary educational management through the string theory lens. S..S. Erçetin (Ed.), Chaos, Complexity and Leadership 2016: Springer Proceedings in Complexity (pp. 51-66). Switzerland: Springer International Publishing, DOI https://doi.org/10.1007/978-3-319-64554-4_5

Erçetin, Ş. Ş., Güngör, H., \& Hamedoğlu, M.A. (2020). Determination of the Factors Affecting Future Expectations of Young People. Journal of Family, Counseling and Education, 5(1), 35-59

Frank, L. K. (1939). Projective methods for the study of personality. The Journal of Psychology, 8(2), 389-413.

Hurn, C. J. (1993). The limits and possibilities of schooling: An introduction to the sociology of education (3rd ed.). Boston: Allyn and Bacon.

İmamoğlu, E. O., \& Güler-Edwards, A. (2007). Geleceğe ilişkin yönelimlerde benlik tipine bağlı farklılıklar. Türk Psikoloji Dergisi, 22(60), 115-132.

Israeli, N. (1930). Some aspects of the social psychology of futurism. Journal of Abnormal and Social Psychology, 25, 121-132.

Israeli, N. (1936). Abnormal personality and time. New York: Science Press.

Lewin, K. (1939). Field theory and experiment in social psychology: concepts and methods. The American Journal of Sociology, 44, 868-897.

Lewin, K. (1948). Resolving social problems. New York: Harper.

Negru, O., Subțirică, A., \& Opre, A. (2011). The dynamics of aspirations in emerging adulthood, in Procedia - Social and Behavioral Sciences, 12, 205-210.

Nuttin, J., \& Lens, W. (1985). Future time perspective and motivation: Theory and research method. NJ: Leuven University Press \& Erlbaum.

Seginer, R. (2003). Adolescent future orientation: An integrated cultural and ecological perspective. Online Readings in Psychology and Culture, 6(1), 3-13.

Şanll, T., \& Saraçll, S. (2015). Üniversite Öğrencilerinin Gelecek Beklentileri Üzerinde Etkili Olan Faktörlerin Analizi [Analysis of Factors Influencing University Students' Future Expectations]. Kafkas Üniversitesi Íktisadi ve İdari Bilimler Fakültesi Dergisi, 6(11), 2536.

Şimşek, H. (2012). Güneydoğu Anadolu Bölgesindeki lise öğrencilerinin gelecek beklentileri ve gelecek beklentilerini etkileyen faktörler [The future expectations of high school students in the Southeastern Anatolia Region and the factors affecting their future expectations]. AKU, Kuramsal Eğitimbilim Dergisi, 5(1), 90-109. 
Tatar, M. (2005). Öğretmen beklentisi [Teacher expectation]. Yüzüncü Yll Üniversitesi Elektronik Ĕ̆itim Fakültesi Dergisi, 2(2), 1-19.

Tuncer, M. (2011a). Ergen Gelecek Beklentileri Ölçeğinin Türkçeye uyarlanması [Adaptation of Adolescent Future Expectations Scale into Turkish]. Turkish Studies - International Periodical For The Languages, Literature and History of Turkish or Turkic Volume, 6(3), 1265-1275

Tuncer, M. (2011b). Yükseköğretim gençliğinin gelecek beklentileri üzerine bir araştırma [A research on the future expectations of higher education youth]. Turkish Studies International Periodical for the Languages, Literature and History of Turkish or Turkic, 6(2), 935-948

Uluçay, T., Özpolat, A.R., İşgör, İ.Y., \& Taşkesen, O. (2014). Lise öğrencilerinin gelecek beklentileri üzerine bir araştırma [A research on the future expectations of high school students]. NWSA-EducationSciences, 9(2), 234-247.

Yavuzer, H., Demir, İ., Meşeci, F., \& Sertelin, Ç. (2005). Günümüz gençliğinin gelecek beklentileri [Future prospects of today's youth]. Hasan Ali Yücel Eğitim Fakültesi Dergisi, 2, 93-103

Zimbardo, P.G., \& Boyd, J.N. (1999). Putting time in perspective: A valid reliable individualdifferences metric. Journal of Personality and Social Psychology, 77(6), 1271-1288. 
The ethics committee approval for this study was obtained from the Ethics Committee of the Rectorate of Hacettepe University, dated 07/01/2020 and numbered 35853172-300.

\section{Statement of Contribution of Researchers to the Article:}

1st author contribution rate: $50 \%$

2nd author contribution rate: $50 \%$

\section{Conflict of Interest Statement:}

There is no conflict of interest.

Statement of Financial Support or Acknowledgment:

No financial support was received from any institution for this study. 